\title{
FARM HOLDINGS AND THE OWNER'S RESIDENCE LOCATION IN THE ASPECT OF DIRECT PAYMENTS FROM THE EU: A CASE STUDY IN NINE REGIONS IN POLAND
}

Katarzyna Kocur-Bera

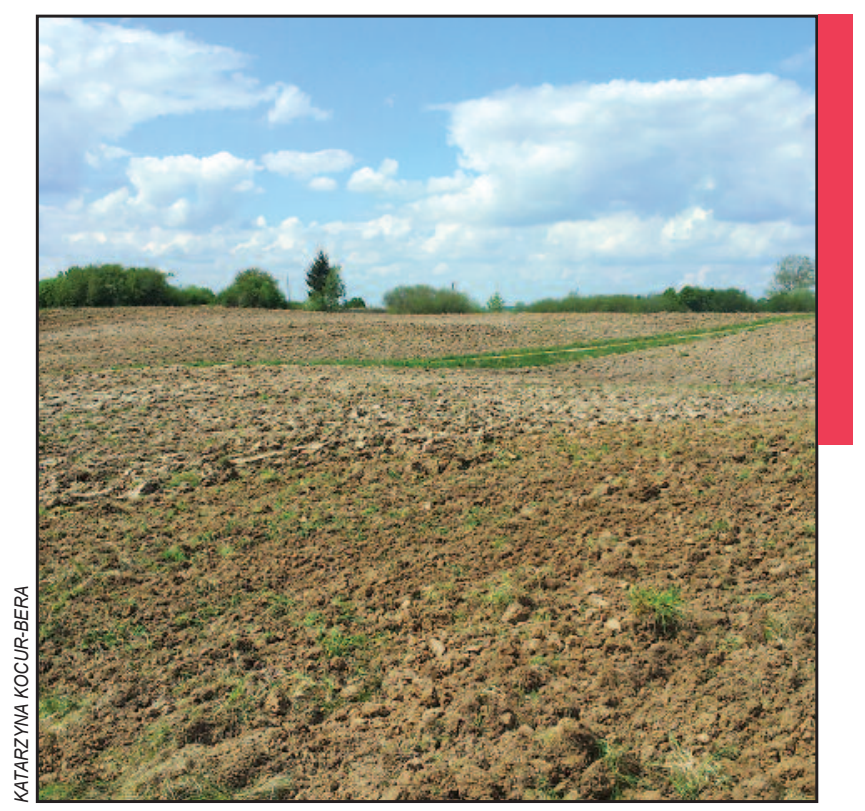

Agricultural areas for cultivation in Poland. 
DOI: https://doi.org/10.3986/AGS.6836

UDC: 332.334.4:63(438)

$338.246 .027(438)$

COBISS: 1.01

\title{
Katarzyna Kocur-Bera ${ }^{1}$
}

\section{Farm holdings and the owner's residence location in the aspect of direct payments from the EU: A case study in nine regions in Poland}

\begin{abstract}
Instruments promoting rural development have been implemented by many countries. Areabased payments for farmers allocated under the Common Agricultural Policy constitute one of such instruments in the European Union. The support system for rural areas, including the size of the declared reference parcels, is monitored as part of the cross-compliance mechanism. Parcels with unfavorable landuse patterns are more difficult to farm. According to estimates, more than $30 \%$ of agricultural farms in Poland fall into this category. This study proposes a universal algorithm for controlling the information submitted by farmers in payment applications. More than 76,000 applications were analyzed, and farms with the defective spatial structure of land were randomly selected. The results show that most errors occur in the case of land parcels situated the farthest from a farm holding (declared in the application), but the analysis revealed no strong correlation in this respect.
\end{abstract}

KEY WORDS: rural area, land spatial structure, area-based payments, cross-compliance monitoring, Common Agricultural Policy, Poland

\section{Kmetijska gospodarstva in lokacije bivališč njihovih lastnikov $z$ vidika neposrednih plačil iz EU: študija primera za del Poljske}

POVZETEK: Številne države imajo instrumente za podporo razvoju podeželja. Ena takih oblik podpore v državah Evropske unije so subvencije za kmetijske površine kmetijskih pridelovalcev, ki se izvajajo v okviru Skupne kmetijske politike. Podporni sistem za podeželje, vključno s površinami, ki jih kmetijski pridelovalec prijavi za subvencije, je predmet nadzora. Kadar imajo parcele pomanjkljivo prostorsko strukturo, je kmetijska dejavnost na njih otežena. Takih posestev kmetijskih pridelovalcev je na Poljskem več kot $30 \%$. Članek predstavlja univerzalen algoritem za izvajanje kontrole podatkov v prijavah kmetijskih pridelovalcev. Analizirali smo več kot 76.000 prijav kmetijskih pridelovalcev, med katerimi smo naključno izbrali skupino kmetijskih pridelovalcev $\mathrm{z}$ razpršeno prostorsko strukturo. Rezultati kažejo, da se večina napak pojavlja pri zemljiščih, ki so najbolj oddaljeni od kmetijskega gospodarstva (navedeni v vlogi), vendar analiza ni pokazala močne korelacije v zvezi s tem.

KLJUČNE BESEDE: podeželje, prostorska struktura zemljišč, subvencije za kmetijske površine, skupna kmetijska politika, spremljanje skladnosti, Poljska

This article was submitted for publication on July $2^{\text {nd }}, 2018$.

Uredništvo je prejelo prispevek 2. julija 2018.

\footnotetext{
${ }^{1}$ University of Warmia and Mazury in Olsztyn, Olsztyn, Poland

katarzyna.kocur@uwm.edu.pl (https://orcid.org/0000-0001-7056-5443)
} 


\section{Introduction}

The main goals of the European Union's Common Agricultural Policy (CAP) are to provide financial support to farmers, increase the competitiveness of agricultural markets in the Member States, increase productivity by promoting technical progress in agriculture, stabilize the agricultural market and guarantee fair incomes and a fair standard of living for the farming community. The last goal is addressed by the area-based payment scheme (Latruffe and Davidova 2007; Zadravec and Zalik 2009; Zygmunt et al. 2015; Janković et al. 2018). Polish farmers became entitled to financial support under the CAP after Poland joined the EU in 2004. Area-based payments are one of the key support instruments for the Polish agricultural sector. The Land Parcel Identification System (LPIS) was originally devised for registering agricultural reference parcels eligible for annual payments under the CAP (Grandgirard and Zielinski 2008; KocurBera and Piórkowska 2018). The LPIS is a computerized system that identifies agricultural (reference) parcels based on aerial and spatial ortho-imagery (Milenov and Kay 2006; EC 2009). It is the key control mechanism to verify the eligibility of reference parcels for direct payments (Sagris and Devos 2008; Zimmermann

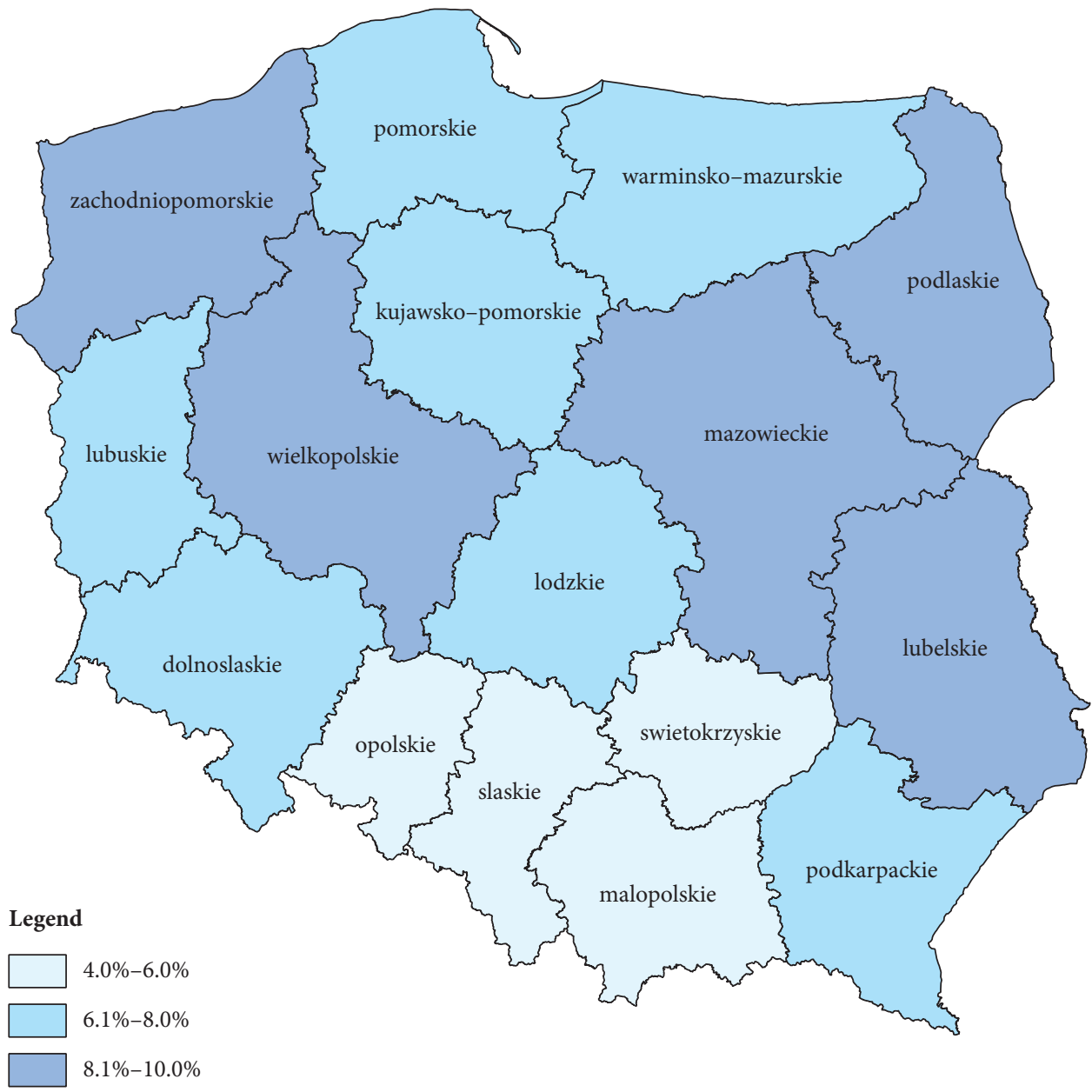

Figure 1: The percentage share of farm holdings in a region, where the farmstead is located farther than $10 \mathrm{~km}$ from the closest cadastral parcel (Kozłowski 2015). 
Katarzyna Kocur-Bera, Farm holdings and the owner's residence location in the aspect of direct payments from the EU ...

et al. 2016). EU Member States have defined reference parcels in different ways as cadastral parcels (CP), agricultural parcels (AP), farmer's blocks (FB) (one or several agricultural parcels cultivated by a single farmer) or physical blocks (PB) (one or several agricultural parcels cultivated by one or several farmers) (Inan and Cete 2007; Sagris and Devos 2008; Inan et al. 2010; Levavasseur et al. 2016; Kocur-Bera 2019). In Poland, a cadastral parcel was accepted as a reference parcel (Kocur-Bera 2019). A reference parcel may contain one or many agricultural parcels declared for aid by one or several farmers, and it is provided with a unique identifier (Inan et al. 2010). An agricultural parcel (AP) determines the subject of the aid application, its geographic location and the extent (area) of the agricultural activity. It represents the land for which payments can be claimed, and it is also a subject of administrative crosschecks and control procedures established in the Integrated Administration and Control System (IACS). Due to the dynamic nature of agricultural activities, an agricultural parcel can be unstable over time and space (Inan et al. 2010; KocurBera and Piórkowska 2018).

The LPIS is the main component of the IACS. Around 5\% of all beneficiaries of CAP programs are inspected for cross-compliance each year. Agricultural producers are required to analyze maps and indicate the size of their reference parcels in the payment application, excluding non-eligible areas and objects such as buildings, yards, shrubs, roads, forests, and lakes. Cross-compliance inspections are not easy to perform, particularly in farms with defective structures. Farms with faulty land spatial structures in Europe result mainly from historical social and economic processes (van Dijk 2003; Vitikainen 2004; Latruffe and Piet 2014; Janus et al. 2016; Leń 2018; Prus and Szylar 2018).

Many researchers focus primarily on land fragmentation, defined as defective spatial structure (Bański 1999; Leń and Noga 2010; Sobolewska-Mikulska 2012; Leń 2018; Noga et al. 2018). Fragmentation is considered to be a comprehensive set of farm holding components, such as size of parcel/ownership, dispersion of parcel, shape of parcel, accessibility of parcel, number of parcel, type of ownership, distance from farmstead (van Dijk 2004; Demetriou, Stillwell and See 2012; Latruffe and Piet 2014; Demetriou 2014; Noga and Król 2016; Leń 2018). The distance between cadastral parcels and the farmstead is one of the attributes of a defective spatial structure(Woch 2001; Harasimowicz, Janus and Ostragowska 2009; Janus 2018). According to Kozłowski (2015), in Poland, in the Zachodniopomorskie and Podlaskie voivodeships, over $10 \%$ of farm holdings have their farmsteads farther than $10 \mathrm{~km}$ from even a single cadastral parcel; in the Wielkopolskie, Mazowieckie and Lubelskie voivodeships - it is 8-10\% of farms; in other seven voivodeships (Podkarpackie, Łódzkie, Dolnośląskie, Lubuskie, Kujawsko-pomorskie, Pomorskie, Warmińsko-mazurskie) it is $6-8 \%$; and $4-6 \%$ in the remaining regions (Figure 1 ).

Agricultural producers are unable to maintain parcels located too far away in good condition due to labor shortages, poor fertilization, high fuel- and time-related costs (Neupane 2000; van Dijk 2003; Niroula and Thapa 2005). Increased production costs, the effect of excessively long distances between parcels, hinder agricultural development and reduce the competitiveness of farmers (Niroula and Thapa 2005). Even a small loss of agricultural payments poses a massive problem because area-based subsidies constitute the main source of income for Polish farmers. The purpose of the research is to examine the impact of the allocation of agricultural producer's residence in relation to agricultural plots that are part of a farm.

The procedure of selecting farms for cross-compliance inspections was described in the first part of the study. The distance of the parcel from the farmstead (owner's residence) influences the quality of agricultural operations and is responsible for the discrepancies between the declared and the measured size of reference parcels. The resulting errors affect the value of financial support granted under the CAP. The correlations between errors in the declared size of reference parcels and other error-promoting factors were analyzed in the second part of the study.

\section{Methods}

Farms applying for area-based payments have to submit an application to the local branch of the national payment agency (the Agency for the Reconstruction and Modernization of Agriculture in Poland). As of 2018, applications have been submitted online (through the eWniosekPlus platform). Written applications are accepted only under extraordinary circumstances, for example, when the applicant does not have Internet access. The applications are checked for completeness, coherence and data content, and the applicant is placed on a list of inspection candidates. Administrative controls can be carried out in a simplified 
or a reference mode. In the simplified mode, the declared information is checked for compliance with the Land Administration System (LAS), whereas in the reference mode, the declared information is compared against the data declared by other farmers (to prevent double funding for the same parcel). The number of inspection candidates is determined at the beginning of each year. Various methods are used to select inspection candidates (Table 1), and most of them involve aerial imaging and on-site visits. Tolerance levels are set for dealing with differences between the declared and the measured size of the parcel. Farms, where tolerance levels are exceeded, are fined.

The case study was carried out by selecting a group of farm holdings where at least one parcel is located at least $5 \mathrm{~km}$ from the farmstead. It was assumed that the farmstead is a farmer's place of residence and the address declared in the EU payment applications. The farms were selected based on the procedure for monitoring cross-compliance in farms receiving area-based payments and the algorithm presented in Table 1. The allocation of cadastral parcels with respect to the farmstead is of particular interest to the control authority (Polish Agency for Restructuring and Modernization of Agriculture). The calculated differences in the parcel area declared in the payment application and the on-site measured area were added up and the general difference for each cadastral parcel was obtained. Subsequently, the errors were added up for each

Table 1: The procedure for monitoring cross-compliance.

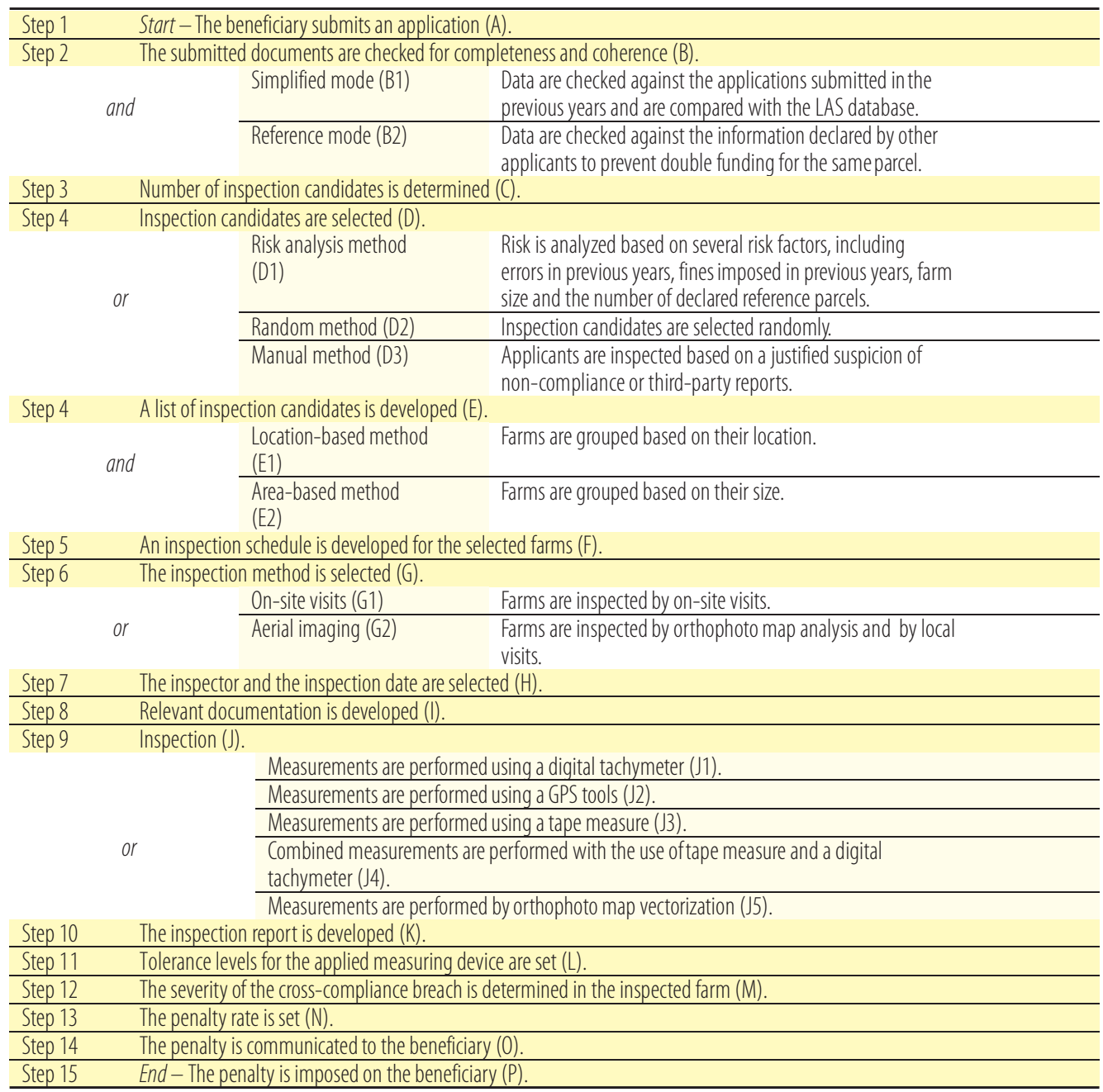


landowner studied. The assumptions made are consistent with the procedure for controlling the landowners. Sanctions and/or penalties are imposed when exceeding specific limits with respect to all cadastral parcels declared for payments from the EU. The distance of every analyzed cadastral parcel was measured from the geometric center of the agricultural parcel and the farmstead (Euclidean distance, in GIS) and it was expressed in kilometers. Initially, approximately 76,000 beneficiaries of CAP support schemes who reside in Poland were evaluated. Ultimately, 216 parcels owned by 18 beneficiaries were selected for analysis. The declared parcels were situated in nine Polish regions: Pomerania (Pomorze), West Pomerania (Zachodniopomorskie), Wielkopolska (Wielkopolskie), Lower Silesia (Dolnośląskie), Swietokrzyskie Voivodeship (Świętokrzyskie), Lodz Voivodeship (Łódkie), Subcarpathia (Podkarpackie), Lubusz Voivodeship (Lubuskie), and Warmia and Mazury (Warmińsko-Mazurskie) (Figure 2).

The difference between the agricultural parcel area (a) declared in the application and the area measured on-site $(\mathrm{m})$ was calculated using the equation:

where:

$$
D_{a p}=\frac{\left(\mathrm{A}_{\mathrm{d}}-\mathrm{A}_{\mathrm{m}}\right)}{\mathrm{A}_{\mathrm{d}}} \cdot 100 \%
$$

$\mathrm{D}_{\text {ap }}$ - difference between the declared $\left(\mathrm{A}_{\mathrm{d}}\right)$ and the measured $\left(\mathrm{A}_{\mathrm{m}}\right)$ agricultural parcel area (error in declared area); $A_{d}$ - agricultural parcel area declared in the application;

$A_{m}$ - agricultural parcel area measured on-site (with GPS tools, tachymeter).

The correlation analysis revealed significant relationships between the observed differences for every cadastral parcel (Diff) and other land-use attributes, such as distribution (Dist), parcel area (Ar), number of parcels in a farm (Disp), number of regions where farm holdings are situated (RD) (Table 2). The observed correlations were interpreted on a six-point scale proposed by J. Guilford (Kocur-Bera 2016a).

Table 2: Description of the land-use attributes.

\begin{tabular}{lllll}
\hline No. & Attribute & Symbol & Description & Measure \\
\hline 1 & Difference & Diff & $\begin{array}{l}\text { Difference between the cadastral parcel area declared in the application } \\
\text { and the area measured on-site. }\end{array}$ & $\%$ \\
\hline 2 & Distance & Dist & $\begin{array}{l}\text { Distance between the cadastral parcel and the landowner's address declared } \\
\text { in an EU application. }\end{array}$ & $\mathrm{km}$ \\
\hline 3 & Area (measured) & Ar & Area of a cadastral parcel. & ha \\
\hline 4 & Dispersion & Disp & A number of cadastral parcel belonging to the landowner. & number \\
\hline 5 & Regional Dispersion & $R D$ & A number of regions where the cadastral parcels belonging to the landowner are situated. & number \\
\hline
\end{tabular}

\section{Results}

Farms were selected for analysis using the algorithm for selecting inspection candidates (Table 1). The analysis relied on the above algorithm to focus solely on farms with an allocation of the owner's residence. Differences for each agricultural parcel were measured and the total sum of errors was calculated in relation to each cadastral parcel. Differences in 216 plots in 18 farms were examined. In 58 cases the difference was different from zero. The results are presented in figure 3.

In $83 \%$ of the parcels where inconsistencies were determined, the declared area was greater than the area used for agricultural production. In $39 \%$ of the analyzed farms, the average difference between the declared area and the measured area did not exceed 3\%; in $44 \%$ of the analyzed farms, the difference was determined at $4-20 \%$; and in $17 \%$ of the analyzed farms, the difference exceeded $20 \%$. The average differences between the area declared in the application and the area measured on-site for evaluated farms are presented in Table 3. 


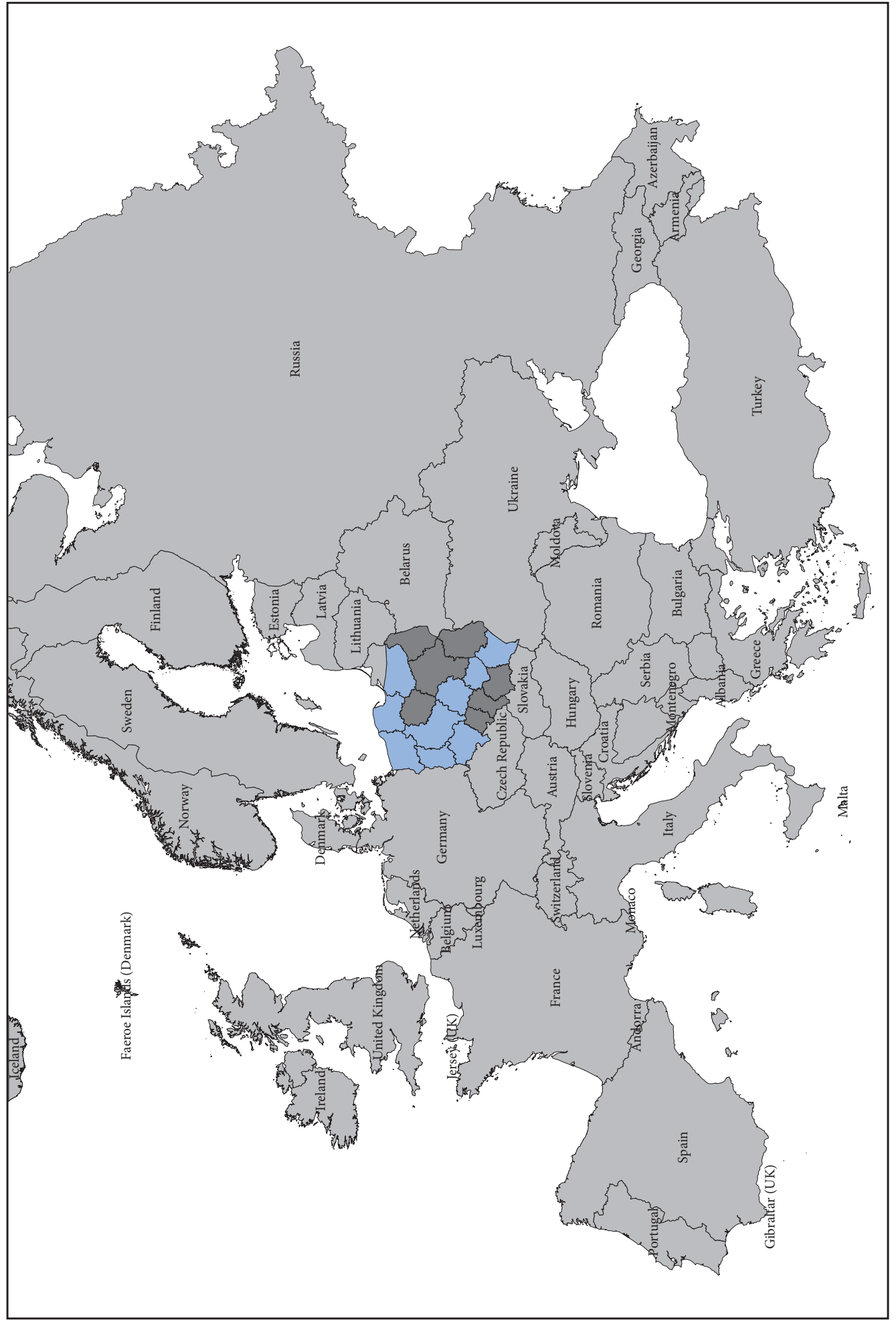


Katarzyna Kocur-Bera, Farm holdings and the owner's residence location in the aspect of direct payments from the EU ...

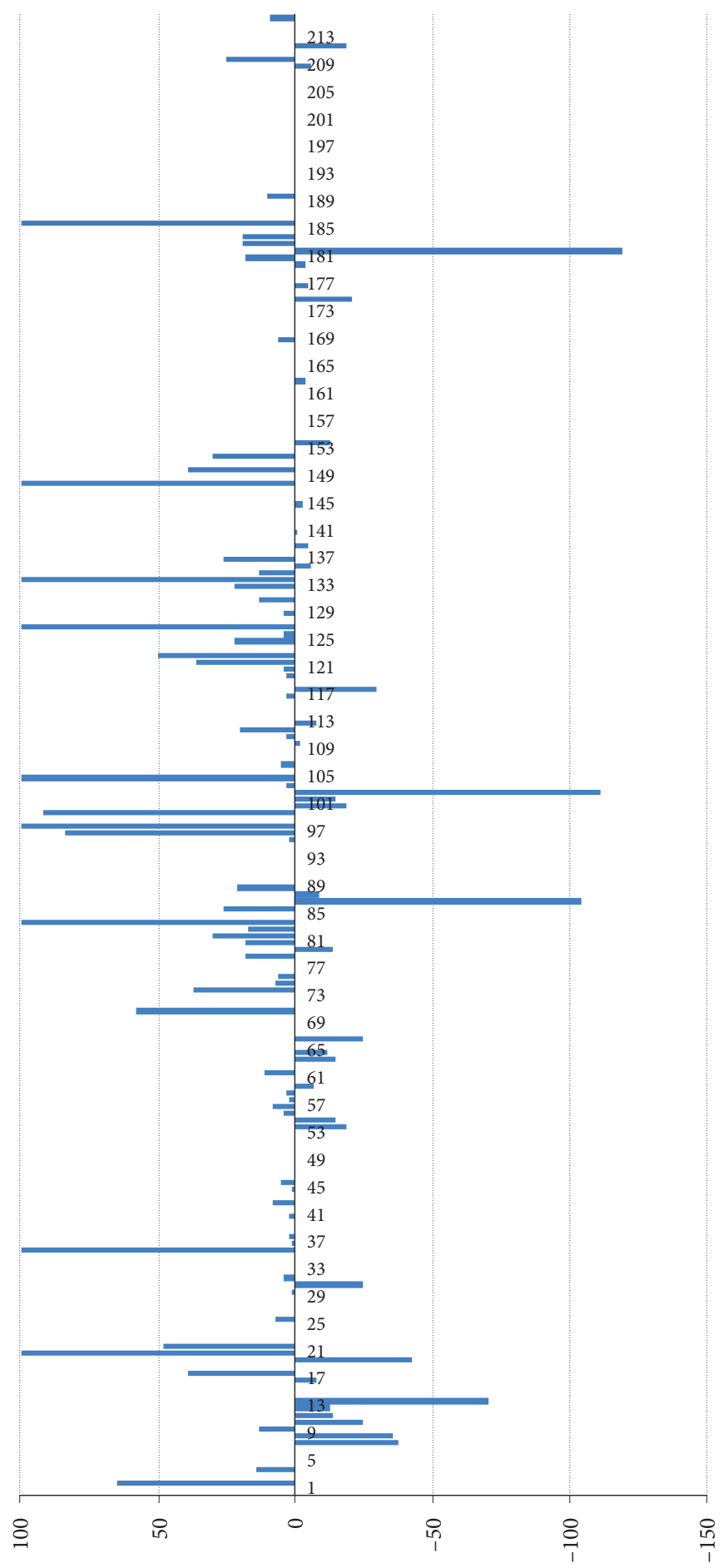


Table 3: The average differences between the parcel area declared in the application and the area measured on-site in the evaluated farms.

\begin{tabular}{|c|c|c|c|c|}
\hline $\begin{array}{l}\text { Number of } \\
\text { landowners }\end{array}$ & $\begin{array}{l}\text { The average differences } \\
\text { in the area of all plots for one } \\
\text { landowner (in one farm) [\%] }\end{array}$ & $\begin{array}{l}\text { Number of cadastral } \\
\text { parcels on the farm }\end{array}$ & $\begin{array}{c}\text { The average distance between } \\
\text { the cadastral parcel and the } \\
\text { landowner's address declared } \\
\text { in application }[\mathrm{km}]\end{array}$ & $\begin{array}{l}\text { Number of regions where the } \\
\text { cadastral parcel belonging } \\
\text { to the landowner are situated }\end{array}$ \\
\hline 1 & -1.06 & 10 & 9.00 & 2 \\
\hline 2 & 25.97 & 12 & 100.00 & 1 \\
\hline 3 & 1.30 & 6 & 10.80 & 2 \\
\hline 4 & 1.48 & 4 & 100.00 & 1 \\
\hline 5 & 56.31 & 4 & 3.75 & 2 \\
\hline 6 & 1.11 & 12 & 48.75 & 2 \\
\hline 7 & 1.97 & 11 & 9.54 & 2 \\
\hline 8 & -8.20 & 9 & 33.33 & 2 \\
\hline 9 & 22.00 & 6 & 100.00 & 1 \\
\hline 10 & 9.66 & 15 & 100.00 & 1 \\
\hline 11 & 16.25 & 18 & 77.22 & 3 \\
\hline 12 & 6.27 & 16 & 89.37 & 3 \\
\hline 13 & 7.44 & 48 & 85.62 & 4 \\
\hline 14 & -4.22 & 8 & 6.87 & 2 \\
\hline 15 & 9.90 & 9 & 2.22 & 2 \\
\hline 16 & 1.17 & 9 & 4.44 & 2 \\
\hline 17 & 0.00 & 7 & 1.43 & 2 \\
\hline 18 & 6.58 & 12 & 2.08 & 2 \\
\hline
\end{tabular}

As the distance between the evaluated parcels and the farmstead was measured it was found that $39 \%$ of the analyzed agricultural parcels were situated at a distance of up to $20 \mathrm{~km}$ from the farmstead (Zone 1), $13 \%$ of the parcels were situated at a distance of $21-50 \mathrm{~km}$ (Zone 2), and $48 \%$ of the parcels were at a distance of more than $50 \mathrm{~km}$ (Zone 3). The percentage differences in the area declared and measured on-site concerned 58 reference parcels, with an average difference of $30.75 \%$. The smallest number of differences was observed in Zone $2(21-50 \mathrm{~km})$, it concerned 15 reference parcels and the average difference was $20.37 \%$. The distribution of individual differences in zones is shown in Figure 4.

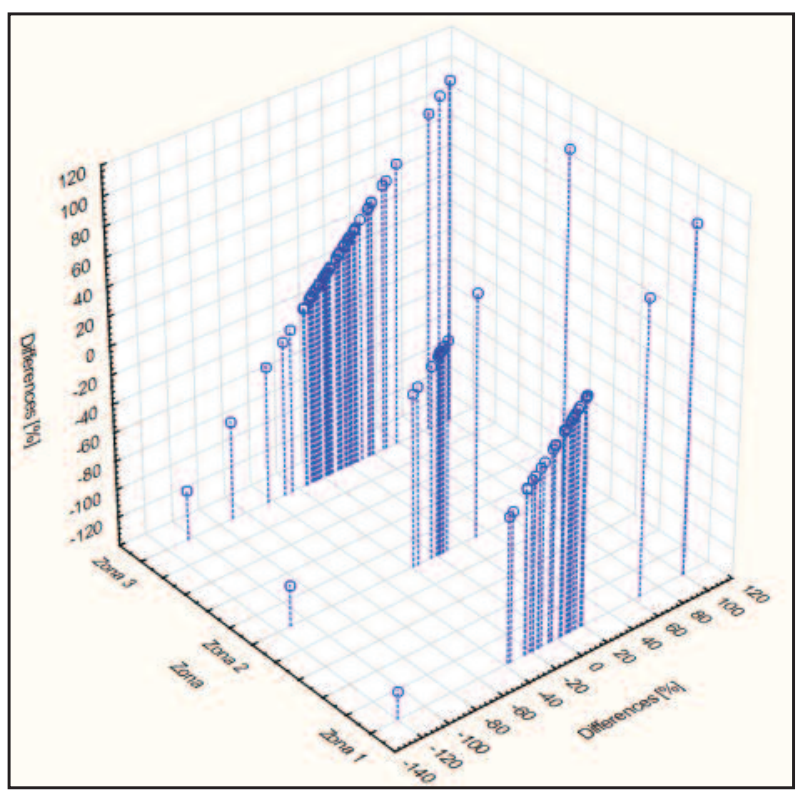

Figure 4: Diagram of the distribution of the percentage differences occurring in individual distance zones. 
Katarzyna Kocur-Bera, Farm holdings and the owner's residence location in the aspect of direct payments from the EU ...

Table 4: Correlation coefficients (Diff - difference between the cadastral parcel area declared in the application and the area measured on-site differences; Dist - Distance between the cadastral parcel and the landowner's address declared in an EU application; Ar - Area of a cadastral parcel.; Disp - A number of cadastral parcel belonging to the landowner; $R D$ - A number of regions where the cadastral parcels belonging to the landowner are situated.

\begin{tabular}{lccccc}
\hline Variable & Diff & Dist & Ar & Disp & RD \\
\hline Diff & 1.0000 & 0.1514 & 0.0030 & 0.0923 & 0.0868 \\
Dist & & 1.0000 & 0.0868 & 0.4622 & 0.2311 \\
Ar & & 1.0000 & -0.0195 & 0.0210 \\
Disp & & & 1.0000 & 0.8621 \\
RD & & & & 1.0000 \\
\hline
\end{tabular}

The calculated Pearson's coefficients (Table 4) were analyzed to reveal that the difference (Diff) between the declared parcel area and the measured on-site was determined by the distance (Dist) between the reference parcel and the landowner's address declared in an EU application. The correlation was weak (according to Guilford's scale weak correlation is $0.1<\mathrm{r} \leq 0.3$ ) and is 0.15 but statistically significant at level of significance $\mathrm{p}<0.05$. The distance between the cadastral parcel and owner's residence (Dist) has a moderate correlation (0.46; according to Guilford's scale moderate correlation is $0.3<\mathrm{r} \leq 0.5$ ) with the number of cadastral parcels of the farm holding (Disp) and have a weak correlation with the number of regions where the cadastral parcels belonging to the landowner are situated $(R D)-0.23$. The number of cadastral parcels on the farm holding (Disp) is strongly correlated (according to Glifford's scale very strong correlation is $0.7<\mathrm{r} \leq 0.9)$ with the number of regions $(R D)$ in which these cadastral parcels are located $(0.86)$.

\section{Discussion}

The study analyzed the impact of localization of landowner's residence (address declared in the application for EU payments) and other factors influencing the error rate reported in EU payment declarations. The existing spatial structure of agricultural land is the result of changes in historical, social, and economic transformations in several generations (Janus 2018). Political transformations in post-socialist countries (including Poland), liquidation of state agricultural companies and privatization of national resources (Bański 2011) rendered it possible to purchase agricultural real estate. Because of no restrictions on buying, people with financial means became landowners. New owners of purchased land situated primarily in locations where the agency (APA) responsible for managing and selling state-owned land (the Agricultural Property Agency of the Treasury in the 1990s; now the Agricultural Property Agency - APA) owned the most of it. This particularly involved the following voivodeships: Warmińsko-Mazurskie, Pomorskie, Kujawskopomorskie, Wielkopolskie, Zachodnio-pomorskie, Dolnośląskie and Lubuskie (Sikorska 2008). Agricultural property purchased was not always located near the farmstead. It was in 2016 when Poland introduced regulations on buying agricultural property (Regulation 2016) which considerably limited the possibility of purchasing such real estate by individuals not engaged in agriculture. In the other Member States like France, Germany, Belgium, Hungary and Latvia, the regulations had been implemented earlier (Nurm 2015; Kocur-Bera 2016b).

This study was oriented towards finding a difference between the area declared for agricultural payments and the area measured on-site using specialist methods and equipment (GPS, total station). The final differences were added up first for the cadastral parcel and ultimately for the farm. 216 cadastral parcels owned by 18 farmers were studied. Differences were discovered in $47 \%$ of the cadastral parcels. In $83 \%$ of the cadastral parcels, the area declared in payment applications was greater than the area measured onsite. All the cases studied were divided into zones, including the landowner's address declared in the payment applications. The highest number of cadastral parcels with differences in the area were in Zone 3. However, the relations observed do not indicate that a greater distance automatically means more errors; differences were found in the cadastral parcels in Zone 1 as well. The least significant differences were spotted in Zone 2. The results were additionally proven by an analysis of Pearson's coefficients. The matrix calculated (Table 4) points to a very weak correlation between the differences and the distance from the cadastral parcel to the landowner's address. The differences discovered were also analyzed considering such features as the area of a parcel declared $(A r)$, the number of cadastral parcels within the farm (Disp), the 
number of regions where cadastral parcels of a single owner are located $(R D)$. The strongest correlation was determined between the the number of cadastral parcels of a single owner (Disp) and the number of regions $(R D)$ where they are situated.

Parcels located far from the farmstead are most often cultivated by employees. The farther the parcels are from the rest of the farm, the higher the costs of production which may even lead to ceasing cultivation (Villanueva and Colombo 2017; Noga et al. 2018). Landowners who engage salaried employees to cultivate parcels situated the farthest do not supervise such employees' work properly, hence possible differences between the area declared and the area measured on-site.

Another reason behind the differences might be the quality of cartographic materials used by landowners to complete payment applications if individual parcels are too far from each other. Data from the Land Administration System (LAS) are not always accurate. Some LAS entries have been developed based on low-quality source materials. The Polish land administration system dates back to the $13^{\text {th }}$-century land management practices and has undergone numerous changes throughout the turbulent history of Central Europe, including wars, conquests, and communism (Siejka et al. 2015). The first digital cadastral maps were developed at the beginning of the 1990s, and contain errors (van Oosterom et al. 2006, Siejka, Ślusarski and Zygmunt 2014; Siejka, Ślusarski and Mika 2015; Noszczyk and Hernik 2017; Mika 2018; KocurBera and Stachelek 2019).

The differences observed may also result from the fact that farmers do not measure areas cultivated on-site. Many farmers declare areas for payments based on, for instance, cartographic materials obtained from the Agency for the Reconstruction and Modernization of Agriculture. Their data are frequently distorted and contain rasterization errors (Tomlinson et al. 2018).

Yet another cause of the differences can be the changes in the guidelines regarding land eligible for payments following the accession of Poland to the EU. For example, in the early years of Poland's membership in the EU, certain elements of the agricultural landscape were not eligible for direct payments, but now they can be (though with some restrictions) (ARMiR 2017).

Farmers who fail to accurately declare the area of reference parcels are fined. If discrepancies are found during an inspection, direct payments to be granted in the calendar year can be reduced or canceled, the farmer can be subjected to long-term sanctions, additional inspections or can be completely excluded from CAP schemes (Pradziadowicz 2014).

The area of agricultural parcels declared by farmers in payment applications and the reliability of LPIS data are controlled in all EU Member States. According to the report 25/2016 of the European Court of Auditors (ECA), the reliability of procedures and data stored in the LPS was verified in Austria, Germany (Saarland and North Rhine-Westphalia), Ireland, Poland and the United Kingdom (Scotland) between July 2015 and April 2016. More than 400 reference parcels were checked on-screen, of which more than 100 were visited on-site. The results of the inspections revealed that ortho-imagery was mostly up to date, but photo-interpretation was not always reliable or conclusive (European court of auditors 2016). The level of error for payments awarded by the European Agricultural Guarantee Fund (EAGF) is estimated each year. In 2014, the level of error was estimated at $2.9 \%$ (2\% materiality threshold) based on 183 audited transactions. Area-related errors accounted for $44 \%$ of the estimated EAGF error rate, but half of these errors were below $2 \%$ (European court of auditors 2016).

\section{Conclusion}

The Common Agricultural Policy was developed to support rural development. Area-based payments are one of the CAP instruments available to the EU Member States. Various procedures (European court of auditors 2016) have been implemented to control spending on area-based payments and to verify whether the beneficiaries comply with the requirements and standards under cross-compliance. The control procedures are similar in the EU Member States, and they are performed annually. The greatest errors are usually noted in the defective spatial structure of the land, but not every breach is intentional. In this study, an analysis of the differences between the parcel area declared in the payment application and the area measured on-site revealed that the distance between a parcel used and the farmstead (owner's address) does not affect the level of error. One may note that most differences occur in the case of parcels located the farthest, although this correlation is statistically weak. The defective spatial structure of land (allocation 
of parcels) can be remedied through land consolidation (Latruffe and Piet 2014; Hendricks and Lisec 2014) and the exchange of parcels. In the sample under study, the reasons behind the phenomenon discussed may be associated with the quality of documents used to complete applications. They vary in quality and sometimes they are of extremely poor quality. That is why the best way to avoid errors is to obtain professionally take measurements on-site prior to submitting each payment application.

ACKNOWLEDGEMENT: This research was financed by the Ministry of Science and Higher Education of the Republic of Poland under grant No. 28.610.015-300.

\section{References}

ARMiR 2017: Sprawozdania z działalności ARiMR 2008-2017. Internet: http://www.arimr.gov.pl (20.5.2018). Bański, J. 1999: Obszary problemowe w rolnictwie Polski. Geographical Studies 172.

Bański, J. 2011: Changes in agricultural land ownership in Poland in the period of the market economy. Agricultural Economics 57-2. DOI: https://doi.org/10.17221/18/2010-AGRICECON

Demetriou, D. 2014: The development of an Integrated Planning and Decision Support System (IPDSS) for Land Consolidation. Cham. DOI: https://doi.org/10.1007/978-3-319-02347-2

Demetriou, D., Stillwell, J., See, L. 2012: Land consolidation in Cyprus: Why is an Integrated Planning and Decision Support System required? Land Use Policy 29-1. DOI: https://doi.org/10.1016/j.landusepol.2011.05.012

European court of auditors 2016: The Land Parcel Identification System: A useful tool to determine the eligibility of agricultural land - but its management could be further improved. Special report 25. DOI: https://doi.org/10.2865/1733

EC, 2009. Council Regulation (EC) No. 73/2009 establishing common rules for direct support schemes for farmers under the common agricultural policy and establishing certain support schemes for farmers, amending Regulations (EC) No. 1290/2005, (EC) No. 247/2006, (EC) No. 378/2007 and repealing Regulation (EC) No. 1782/2003

Grandgirard, D., Zielinski, R. 2008: Land Parcel Identification System (LPIS) Anomalies' Sampling and Spatial Pattern. Towards convergence of ecological methodologies and GIS technologies. European Commission, Joint Research Centre Institute for the Protection and Security of the Citizen. Luxembourg.

Harasimowicz, S., Janus, J., Ostragowska, B. 2009: Optymalizacja przydziału gruntów do gospodarstw i jej powiązanie ze strefami różnic odległości z siedlisk do działek. Infrastruktura i ekologia terenów wiejskich 5.

Hendricks, A., Lisec, A. 2014: Komasacije pri velikih infrastrukturnih projektih v Nemčiji. Geodetski vestnik 58-1. DOI: https://doi.org/10.15292/geodetski-vestnik.2014.01.046-068

Inan, H. I., Cete, M. 2007: Evaluation of land parcel identification systems. Strategic Integration of Surveying Services FIG Working Week 13.-17. May 2007 Hong Kong. China.

Inan, H. I., Sagris, V., Devos, W., Milenov, P., van Oosterom, P., Zevenbergen, J. 2010: Data model for the collaboration between land administration systems and agricultural land parcel identification systems. Journal of Environmental Management 91-12. DOI: https://doi.org/10.1016/j.jenvman.2010.06.030

Janković, N., Govedarica, M., Navratil, G., Fogliaroni, P. 2018: Domain model of an agricultural information system based on standards. Geodetski vestnik 62-1. DOI: https://doi.org/10.15292/geodetski-vestnik.2018.01.51-67

Janus, J. 2018: Measuring land fragmentation considering the shape of transportation network: A method to increase the accuracy of modeling the spatial structure of agriculture with case study in Poland. Computers and Electronics in Agriculture 148. DOI: https://doi.org/10.1016/j.compag.2018.03.016

Janus, J., Mika, M., Leń, P., Siejka, M., Taszakowski, J. 2016: A new approach to calculate the land fragmentation indicators taking into account the adjacent plots. Survey Review 50. DOI: https://doi.org/ $10.1080 / 00396265.2016 .1210362$

Kocur-Bera, K. 2016a: Kształtowanie bezpiecznej przestrzeni obszarów wiejskich w aspekcie występowania ekstremalnych zjawiska pogodowych. Olsztyn.

Kocur-Bera, K. 2016b: Determinants of agricultural land price in Poland - a case study covering a part of the Euroregion Baltic. Cahiers Agricultures 25-2. DOI: https://doi.org/10.1051/cagri/2016013 
Kocur-Bera, K. 2019: Data compatibility between the Land and Building Cadaster (LBC) and the Land Parcel Identification System (LPIS) in the context of area-based payments: a case study in the Polish Region of Warmia and Mazury. Land Use Policy 80. DOI: https://doi.org/10.1016/j.landusepol.2018.09.024

Kocur-Bera, K., Piórkowska, K. 2018: The role of the Land Administration System in the process of developing and updating the Land Parcel Identification System - a case study of high nature value farmland in north-eastern Poland. Geographic Information Systems Conference and Exhibition »GIS ODYSSEY 2018 «, Italy 10th to 14th of September 2018. Perugia.

Kocur-Bera, K., Stachelek, M. 2019: Geo-Analysis of Compatibility Determinants for Data in the Land and Property Register (LPR). Geosciences 9-7. DOI: https://doi.org/10.3390/geosciences9070303

Kozłowski, J. 2015: Obecna i perspektywiczna rola geodezji i kartografii w zaspokajaniu potrzeb innych sektorów administracji i gospodarki. Problematyka geodezyjna w sektorze rolnym. Ministerstwo Rolnictwa i Rozwoju Wsi. Materiały z posiedzenia Państwowej Rady Geodezyjnej i Kartograficznej. Warszawa.

Latruffe, L., Davidova, S. 2007: Common Agricultural Policy direct payments and distributional conflicts over rented land within corporate farms in the New Member States. Land Use Policy 24-2. DOI: https://doi.org/ 10.1016/j.landusepol.2006.06.003

Latruffe, L., Piet, L. 2014: Does land fragmentation affect farm performance? A case study from Brittany, France. Agricultural Systems 129. DOI: https://doi.org/10.1016/j.agsy.2014.05.005

Leń, P. 2018: An algorithm for selecting groups of factors for prioritization of land consolidation in rural areas. Computers and Electronics in Agriculture 144. DOI: https://doi.org/10.1016/j.compag.2017.12.014

Leń, P., Noga, K. 2010: Analiza rozdrobnienia gruntów indywidualnych we wsiach powiatu Brzozów. Infrastruktura i Ekologia Terenów Wiejskich 3.

Levavasseur, F., Martin, P., Bouty, C., Barbottin, A., Bretagnolle, V., Thérond, O., Scheurer, O., Piskiewicz, N. 2016: RPG Explorer: A new tool to ease the analysis of agricultural landscape dynamics with the Land Parcel Identification System. Computers and Electronics in Agriculture 127. DOI: https://doi.org/ 10.1016/j.compag.2016.07.015

Mika, M. 2018: An analysis of possibilities for the establishment of a multipurpose and multidimensional cadaster in Poland. Land Use Policy 77. DOI: https://doi.org/10.1016/j.landusepol.2018.05.060

Milenov, P., Kay, S. 2006: Status of the implementation of LPIS in the EU Member States. Proceedings of the 12th MARS PAC Annual Conference. Toulouse.

Neupane, R. P. 2000: Prospects of Agroforestry promotion in the mountains of Nepal. Ph. D. thesis, Asian Institute of Technology. Bangkok.

Niroula, G., Thapa, G. 2005: Impacts and causes of land fragmentation, and lesson learned from land consolidation in South Asia. Land Use Policy 22-4. DOI: https://doi.org/10.1016/j.landusepol.2004.10.001

Noga, K., Król, Ż. 2016: The patchwork of land as a problem restricting the development of rural areas. Barometr Regionalny 14-3.

Noga, K., Sosnowski, Z., Balawejder, M., Matkowska, K., Mazur, A. 2018: Ocena przeprowadzonych scaleń i wymiany gruntów rolnych województwa podkarpackiego pod katem barier ograniczających ich realizację. Warszawa.

Noszczyk, T., Hernik, J. 2017: Potrzeba czynnego prowadzenia ewidencji gruntów i budynków. Infrastruktura i Ekologia Terenów Wiejskich 1. DOI: https://doi.org/10.14597/infraeco.2017.1.2.017

Nurm, K. 2015: Opinion of the European Economic and Social Committee on »Land grabbing - a warning for Europe and a threat to family farming «. Official Journal of the European Union C 242-15. Brussels.

Pradziadowicz, M. 2014: Control of the farms under the Rural Development Programme 2007-2013. Folia Pomeranae Universitatis Technologiae Stetinensis, Oeconomica 3.

Prus, B., Szylar, M. 2018: The analysis of settlement network's dispersion using Ward's taxonomy method, Survey Review. DOI: http://doi.org/10.1080/00396265.2017.1418279

Regulation 2016: Act of April 14th 2016 o wstrzymaniu sprzedaży nieruchomości Zasobu Własności Rolnej Skarbu Państwa oraz o zmianie niektórych ustaw 585.

Sagris, V., Devos, W. 2008: LPIS core conceptual model: methodology for feature catalogue and application Schema. European Commission, Joint Research Centre Institute for the Protection and Security of the Citizen. Luxembourg.

Siejka, M., Ślusarski, M., Zygmunt, M. 2014: Verification technology for topological errors in official databases with case study in Poland. Survey Review 46-334. DOI: https://doi.org/10.1179/1752270613Y.0000000054 
Siejka, M., Ślusarski, Z., Mika, M. 2015: Legal and technical aspects of modernization of land and buildings cadastre in selected area. Reports of Geodesy and Geoinformatics 99-1. DOI: https://doi.org/ 10.2478/rgg-2015-0011

Sikorska, A. 2008: Rynek ziemi rolnej stan i perspektywy. Analizy rynkowe. Warszawa.

Sobolewska-Mikulska, K. 2012: Możliwości wykorzystania scaleń infrastrukturalnych w procesie przebudowy struktury przestrzennej obszarów wiejskich. Infrastruktura i Ekologia Terenów Wiejskich 1-2.

Tomlinson, S. J., Dragosits, U., Levy, P. E., Thomson, A. M., Moxley, J. 2018: Quantifying gross vs. net agricultural land use change in Great Britain using the Integrated Administration and Control System. Science of The Total Environment 628-629. DOI: https://doi.org/10.1016/j.scitotenv.2018.02.067

Van Dijk T. 2004: Land consolidation as Central Europe's Panacea reassessed. Proceedings of Symposium on Modern Land Consolidation, 10th and 11th September, 2004. Volvic.

van Dijk, T. 2003: Scenarios of Central European land fragmentation. Land Use Policy 20-2. DOI: https://doi.org/10.1016/S0264-8377(02)00082-0

Van Oosterom, P., Lemmen, C., Ingvarsson, T., van der Molen, P., Ploeger, H., Quak, W., Stoter, J., Zevenbergen, J. 2006: The Core Cadastral Domain Model. Computer, Environment and Urban Systems 30.

Villanueva, M. P., Colombo, S. 2017: Cost analysis of parcel fragmentation in agriculture: the case of traditional olive cultivation. Biosystems Engineering 164. DOI: https:/doi.org/10.1016/j.biosystemseng.2017.10.003

Vitikainen, A. 2004: An overview of land consolidation in Europe. Nordic Journal of Surveying Real Estate Research 1-1. DOI: https://journal.fi/njs/article/view/41504

Woch, F. 2001: Optymalne parametry rozłogu gruntów gospodarstw rodzinnych dla terenów wyżynnych Polski. Pamiętnik Puławski 127. Puławy.

Zadravec, M., Žalik, B. 2009: A geometric and topological system for supporting agricultural subsidies in Slovenia. Computers and Electronics in Agriculture 69-1. DOI: https://doi.org/10.1016/j.compag.2009.07.010

Zimmermann, J., González, A., Jones, M. B, O’Brien, P., Stout, J. C., Green, S. 2016: Assessing land-use history for reporting on cropland dynamics - A comparison between the Land-Parcel Identification System and traditional inter-annual approaches. Land Use Policy 52. DOI: https://doi.org/10.1016/ j.landusepol.2015.11.027

Zygmunt, M., Siejka, M., Ślusarski, M., Siejka, Z., Piech, I., Bacior, S. 2015: Database inconsistency errors correction, on example of LPIS databases in Poland. Survey Review 47-343. DOI: https://doi.org/ $10.1179 / 1752270614$ Y.0000000134 